CZASOPISMO INŻYNIERII LĄDOWEJ, ŚRODOWISKA I ARCHITEKTURY JOURNAL OF CIVIL ENGINEERING, ENVIRONMENT AND ARCHITECTURE JCEEA, t. XXXIII, z. 63 (2/I/16), kwiecień-czerwiec 2016, s. 157-169

\author{
Katarzyna MAJ ${ }^{1}$ \\ Piotr KOSZELNIK ${ }^{2}$
}

\title{
METODY ZAGOSPODAROWANIA OSADÓW DENNYCH
}

\begin{abstract}
Osady denne są nagromadzonym materiałem osadowym, który odkłada się systematycznie zmniejszając pojemność retencyjną zbiorników wodnych. Usuwanie osadów jest jedną z metod rekultywacji wód powierzchniowych. Wydobyte osady denne, które nie zawierają substancji szkodliwych mogą być wykorzystane lub odpowiednio składowane. Skład osadów dennych jest uzależniony od czynników naturalnych i antropogenicznych, głównie punktowych i obszarowych źródeł zanieczyszczeń. W wyników procesów samooczyszczania się, znaczna część zanieczyszczeń z wód zbiorników wodnych przedostaje się do osadów dennych, gdzie są zatrzymywane. $Z$ tego powodu skład osadów dennych i wód powierzchniowych są od siebie zależne. Zależność ta jest zauważalne szczególnie w przypadku zanieczyszczeń, które charakteryzują się małą rozpuszczalnością oraz trudno ulegające biodegradacji, takich jak sole metali ciężkich i trwałe związki organiczne. Wybór sposobu zagospodarowania osadów dennych jest zależny od ich właściwości chemicznych i fizycznych. Możliwe jest wykorzystanie niezanieczyszczonych osadów dennych przyrodniczo, w budownictwie i do produkcji energii cieplnej. W pracy przedstawiono możliwości wykorzystania osadów dennych oraz kryteria decydujące o sposobie ich zagospodarowania. Na podstawie omówionych kryteriów zaproponowano schemat postępowania z pozyskanymi osadami dennymi.
\end{abstract}

Słowa kluczowe: osady denne, zbiorniki wodne, jakość osadów dennych , zanieczyszczenia osadów dennych

\section{Wprowadzenie}

Osady denne to materiał osadowy wydobyty z dna rzek i zbiorników wodnych. Materiał zawieszony w wodzie sedymentuje, co powoduje powstanie materii osadowej. Jest to naturalny element ekosystemu wodnego zawierający za-

\footnotetext{
${ }^{1}$ Katarzyna Maj, Politechnika Rzeszowska, Zakład Inżynierii i Chemii Środowiska, Wydział Budownictwa, Inżynierii Środowiska i Architektury, 35-959 Rzeszów, al. Powstańców Warszawy 12, e-mail: kmaj@stud.prz.edu.pl

2 Autor do korespondencji: Piotr Koszelnik, Politechnika Rzeszowska, Zakład Inżynierii i Chemii Środowiska, Wydział Budownictwa, Inżynierii Środowiska i Architektury, 35-959 Rzeszów, al. Powstańców Warszawy 12, tel. + 48 (017) 865 1065, e-mail: pkoszel@prz.edu.pl
} 
równo substancje organiczne jak i nieorganiczne ,naturalne jak i antropogeniczne. Nadmierne nagromadzenie osadów dennych przyczynia się do zmniejszenia pojemności oraz głębokości ograniczając walory użytkowe zbiorników wodnych. Ze względu na szybkie tempo nagromadzania się nadmiaru osadów dennych, zwłaszcza w małych zbiornikach wodnych, należy jest okresowo usuwać $[15,29,37]$.

Po każdym zabiegu bagrowania należy odpowiednio zagospodarować bądź unieszkodliwić pozyskane osady denne, w zależności od stopnia ich zanieczyszczenia. Zagospodarowanie osadów dennych może być skuteczną metoda na osiąganie zysków większych niż koszty poniesione usuwanie osadów dennych ze zbiorników wodnych. Ze względu na częste zanieczyszczenia wydobytego materiału konieczne jest przeprowadzenie badań niezbędnych do oceny jakości osadów dennych, na podstawie których można rozważać warianty ich zagospodarowaniu, a w przypadku kiedy nie spełniają wymogów do ich składowania lub unieszkodliwiania $[29,32]$.

Przedstawione metody wykorzystania osadów dennych zostały zaprezentowane w oparciu o dane literaturowe $\mathrm{z}$ ostatnich lat.

\section{Kryteria klasyfikacji osadów dennych}

Przed wykorzystaniem osadów ocenie poddawana jest ich jakość, co pozwala na rozdział osadów zanieczyszczonych od niezanieczyszczonych. Oceniając możliwości wykorzystania osadów dennych należy uwzględnić Rozporządzenie Ministra Środowiska z dnia 9 września 2002 r. w sprawie standardów jakości gleby oraz standardów jakości ziemi [35], nieaktualne Rozporządzenie Ministra Środowiska z dnia 16 kwietnia 2002 r. w sprawie rodzajów oraz stężeń substancji, które powoduja, że urobek jest zanieczyszczony [34] oraz Ustawę z dnia 14 grudnia 2012 r. o odpadach [44]. Uwzględnienie do oceny osadów dennych nieaktualnego Rozporządzenie Ministra Środowiska z dnia 16 kwietnia 2002 r. [34] jest uwarunkowane brakiem obecnie innej normy, która klasyfikowałaby osady denne pod kątem zanieczyszczenia substancjami szkodliwymi $[20,41]$.

Zgodnie z Ustawą o odpadach [44] osady denne są uznawane za odpad. W załączniku nr 3 do tej Ustawy [44] zamieszczono wykaz właściwości, które decydują o tym czy odpad jest niebezpieczny. Identyfikacja co najmniej jednej z tych właściwości determinuje przyporządkowanie urobku do grupy odpadów niebezpiecznych. Podobnie należy postępować z załącznikiem nr 4 do tej samej Ustawy [44]. Na podstawie Katalogu odpadów załączonego do Rozporządzenia Ministra Środowiska z dnia 9 grudnia 2014 r. w sprawie katalogu odpadów [36] osady denne są przyporządkowane do właściwej grupy odpadów. Osady denne zawierające lub zanieczyszczone substancjami niebezpiecznymi są klasyfikowane jako odpad niebezpieczny o kodzie 1705 . Z kolei zapis art. 7 Ustawy o odpadach [44] umożliwia zmianę klasyfikacji odpadu niebezpiecznego na inny niż 
niebezpieczny pod warunkiem wykazania, że dany odpad nie posiada właściwości charakteryzujących odpady niebezpieczne zdefiniowanych w załączniku $\mathrm{nr} 3$ do Ustawy o odpadach [44]. Natomiast osady denne niezanieczyszczone substancjami niebezpiecznymi należą do odpadów o kodzie 170506 (urobek z pogłębiania inny niż wymieniony w 170505 ).

Rodzaje oraz dopuszczalne stężenia substancji, które mogą powodować, że osady denne pochodzące z pogłębiania zbiorników wodnych są zanieczyszczone ujęto w Rozporządzeniu Ministra Środowiska w sprawie rodzajów oraz stężeń substancji, które powodują, że urobek jest zanieczyszczony [34]. Osady denne (urobek) są uważane za zanieczyszczone, jeżeli któryś wskaźnik osiągnie wartość równą lub większą niż dopuszczalna (Tabela 1).

Tabela 1. Rodzaje oraz stężenia substancji, które powodują, że urobek jest zanieczyszczony, na podstawie [34]

Table 1 . The types and concentrations of substances that cause the dredged material is contaminated, based on [34]

\begin{tabular}{|l|c|l|c|}
\hline \multicolumn{1}{|c|}{ Związek } & $\begin{array}{c}\text { Wartość dopusz- } \\
\text { czalna } \\
\text { [mg/kg s.m.] }\end{array}$ & \multicolumn{1}{c|}{ Związek } & $\begin{array}{c}\text { Wartość dopusz- } \\
\text { czalna } \\
\text { [mg/kg s.m.] }\end{array}$ \\
\hline metale & 30 & benzo(a)antracen & \multicolumn{2}{c|}{ związki organiczne } \\
\hline arsen & 200 & benzo(b)fluoranten & 1,5 \\
\hline chrom & 1000 & benzo(k)fluoranten & 1,5 \\
\hline cynk & 7,5 & benzo(ghi)perpylen & 1,0 \\
\hline kadm & 150 & benzo(a)piren & 1,0 \\
\hline miedź & 75 & dibenzo(a,h)antracen & 1,0 \\
\hline nikiel & 200 & indeno(1,2,3-c,d)ipiren & 1,0 \\
\hline ołów & 1,0 & $\sum$ PCB & 0,3 \\
\hline rtęć & &
\end{tabular}

W odniesieniu do zapisów zawartych w Rozporządzeniu Ministra Środowiska w sprawie standardów jakości gleby oraz standardów jakości ziemi [35] należy uznać za zanieczyszczone osady denne gdzie przekroczone są dopuszczalne stężenia substancji ujęte w Załączniku do tego Rozporządzenia [35]. Rozporządzenie to uwzględnienia funkcje gleby i ziemi (w tym osadów dennych) aktualną i planowaną dla 3 rodzajów gruntów omówionych w tabeli 2. Przekroczenie wartości dopuszczalnej dla gruntów z grupy $\mathrm{C}$ powoduje, że osad denny nie jest klasyfikowany do zagospodarowania i dalsze postępowanie z nim należy oprzeć na zapisach Rozporządzenia Ministra Gospodarki z dnia 8 stycznia 2013 r. w sprawie kryteriów oraz procedur dopuszczania odpadów do składowania na składowisku odpadów danego typu $[33,41]$. 
Tabela 2. Grupy rodzajów gruntów zgodnie z RMŚ z dnia 9 września 2002 r. w sprawie standardów jakości gleby oraz standardów jakości ziemi, na podstawie [35]

Table 2. A group of types of land in accordance with RMŚ of 9 September 2002 on the quality of soil and earth quality standards, based on [35]

\begin{tabular}{|l|}
\hline Grupa A \\
\hline - obszary wodne poddane przepisom ustawy Prawo wodne i przepisom o ochronie \\
przyrody; nieruchomości gruntowe wchodzące w skład obszaru poddanego ochro- \\
nie na podstawie przepisów ustawy - Prawo wodne, \\
- obszary poddane ochronie na podstawie przepisów o ochronie przyrody; jeżeli \\
utrzymanie aktualnego poziomu zanieczyszczenia gruntów nie stwarza zagrożenia \\
dla zdrowia lub środowiska - dla obszarów tych stężenia zachowują standardy wy- \\
nikające ze stanu faktycznego, z zastrzeżeniem pkt. 2 i 3; \\
\hline Grupa B \\
\hline - grunty zaliczone do użytków rolnych z wyłączeniem gruntów pod stawami i grun- \\
tów pod rowami, grunty leśne oraz zadrzewione i zakrzewione, nieużytki, a także \\
grunty zabudowane i zurbanizowane z wyłączeniem terenów przemysłowych, użyt- \\
ków kopanych oraz terenów komunikacyjnych; \\
\hline Grupa C \\
\hline - tereny przemysłowe, użytki kopalne, tereny komunikacyjne. \\
\hline
\end{tabular}

Na podstawie omówionych kryteriów opracowano schemat postępowania $\mathrm{z}$ osadami dennymi zaprezentowany na rysunku 1 .

\section{Kierunki zagospodarowania osadów dennych}

Po ustaleniu na podstawie polskich norm prawnych [34-36, 44], że urobek jest odpadem innym niż niebezpieczny można rozpatrywać sposoby odzysku odpadu poprzez ich racjonalne zagospodarowanie. Należy uwzględnić sposób ich oddziaływania, przede wszystkim interpretując czy nie stwarzają dla środowiska zagrożenia przez uwalnianie substancji szkodliwych [37].

Główne kierunki zagospodarowania osadów dennych przedstawia rysunek 2.

\subsection{Zagospodarowanie przyrodnicze}

Pozyskane w wyniku bagrowania osady denne mogą być wykorzystane przyrodniczo w rolnictwie do nawożenia i do rekultywacji terenów zdegradowanych [12]. Niektóre osady denne mogą pełnić funkcje naturalnych nawozów, ponieważ wydobyte $\mathrm{z}$ dna zbiorników wodnych oraz rzek są bogatym źródłem materii organicznej i łatwo przyswajalnych związków organicznych $[8,13,31]$. O ich wykorzystaniu do celów rolniczych decyduje zawartość metali ciężkich i zawartość przyswajalnych form $\mathrm{Mg}, \mathrm{K}$ i P, które świadczą o żyzności osadów. Problemem przy ich stosowaniu do celów rolniczych może być duże zanieczyszczenie metalami ciężkimi i związkami organicznymi (jak pestycydy, WWA, PCB, substancje ropopochodne) [5,9,20,31]. 


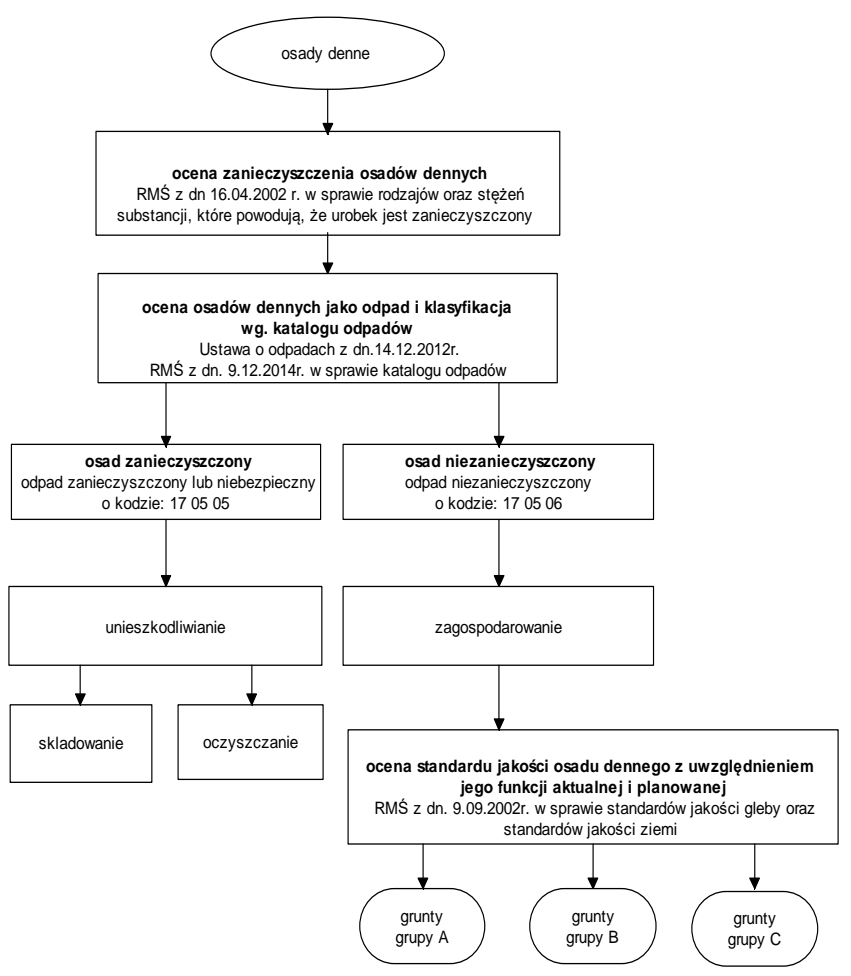

Rys. 1. Proponowany schemat wykorzystania wydobytych osadów dennych [opracowanie własne]

Fig. 1. The proposed diagram of the dredged bottom sediment use [own elaboration]

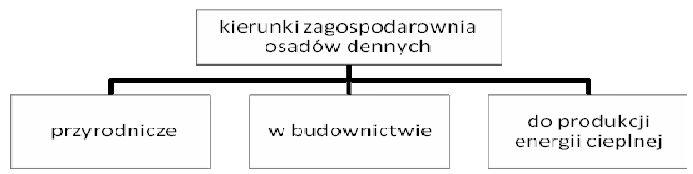

Rys.2 . Główne kierunki zagospodarowania osadów dennych [opracowanie własne]

Fig.2. The main directions of bottom sediment the management of [own elaboration]

Nawozy wg Ustawy o nawozach i nawożeniu [43] są produktami, które dostarczają roślinom składników pokarmowych lub zwiększają żyzność gleby albo stawów rybnych, a za takie uznaje się nawozy mineralne, naturalne i organicznomineralne [43]. Podana we wspomnianej Ustawie [43] definicja nawozów naturalnych nie uwzględnia osadów dennych, dlatego przed ich zastosowaniem do celów nawozowych należy spełnić wymagania określone w RMŚ w sprawie standardów jakości gleby oraz standardów jakości ziemi [35]. 
Możliwości zagospodarowania $\mathrm{w}$ rolnictwie osadów dennych $\mathrm{z}$ różnych zbiorników z pozytywnym skutkiem rozpatrywali m.in.: Gałka i Witkowski [15], Madeyski i Tarnawski [27,28], Kozlovska i in. [25] czy Fonseca i in. [13]. Stanińska i in. [39] przeprowadzili badania oceniające osady denne jeziora Malta w kierunku ich rolniczego wykorzystania. Osady uznano za niezanieczyszczone, poziom koncentracji metali ciężkich zezwalał na wykorzystanie ich jako nawozu dla gleb rolnych ubogich w związki biogenne oraz materię organiczną [39]. Podobnie Bąk i in. [6] badali osady denne zbiornika wodnego w Kaniowie. Zawartości metali ciężkich zakumulowanych w osadach tego zbiornika zostały przekroczone jedynie w przypadku ołowiu, osady przyporządkowano pod względem chemicznym gruntom grupy B [35], więc mogły być wykorzystywane rolniczo.

Osady denne pochodzące ze zbiornika zaporowego w Rzeszowie badane przez Bartoszek i in. [4], nie spełniają wymagań stawianych do wykorzystania w rolnictwie, z uwagi na występujące w nich zanieczyszczenia i małą żyzność. Mogą być jednak użyte do rekultywacji gruntów na terenach nierolniczych. Natomiast analizy przeprowadzone przez Kużdżał $i$ in. [26] oraz Tomczuk i in. [42] wykazały nieprzydatność osadów dennych pochodzących z rzeki Kłodnicy oraz zbiornia Klimkówka do zastosowania rolniczego, ponieważ zostały zaklasyfikowane do gruntów grupy C wg RMŚ sprawie standardów jakości gleby oraz standardów jakości ziemi [35].

Badania opisane w literaturze wskazują, że dodatek osadów dennych do gleb lekkich poprawia ich produktywność, wpływając na poprawę ich właściwości fizykochemicznych [12]. Pod takim kątem badania prowadzili Baran i in. [3], gdzie oceniono wpływ osadu dennego na zmiany wybranych właściwości fizykochemicznych gleby lekkiej. Badania prowadzono dla gleb piaszczysto słabogliniastych dodając do nich osad denny w stosunku 5\% i 10\% do suchej masy gleby. Osady denne pochodziły ze zbiornika retencyjnego w Zesławicach, ich jakość spełniała kryteria, zwłaszcza dotyczące metali ciężkich dla gleby i ziemi grupy B. Po 2 latach badań stwierdzono zmniejszenie zakwaszenia gleby oraz zwiększony stopień wysycenia kompleksu sorpcyjnego zasadami, w obu przypadkach odpowiednio o $5 \%$ i $10 \%$, Wykazano korzystny wpływ dodatku osadów dennych do gleby lekkiej z uwagi na jej neutralizacje, co potwierdzają również badania przeprowadzone przez Arasimowicz i in. [1,2], Wiśniowska-Kielan i in. [45].

Badania przeprowadzone przez Jasiewicz $\mathrm{i}$ in. [19] pokazują pozytywny aspekt aplikacji osadów dennych do gleby lekkiej stanowiącej podłoże w uprawach kukurydzy, a mianowicie zmniejszenie bioakumulacji metali ciężkich: $\mathrm{Cu}$, $\mathrm{Cd}$, i Zn w biomasie. Dodatek osadu dennego w ilości 5\% do gleby spowodował obniżenie zawartości metali ciężkich w części nadziemnej rośliny. Jednak dodatek osadu dennego ubogiego w związki mineralne nie koniecznie musi wpłynąć korzystnie na wzrost plonów kukurydzy, jak miało to miejsce w badaniach przeprowadzonych przez Niemca [30].

Przykładem zastosowania osadów dennych do rekultywacji terenów jest renowacja parku dworskiego we Wrocławiu-Pawłowicach [14]. Osady denne 
pochodzące $\mathrm{z}$ małych obiektów wodnych zlokalizowanych $\mathrm{w}$ tym parku zostały przebadane, nie stwierdzono $w$ nich przekroczenia dopuszczalnych wartości zanieczyszczeń. Zagospodarowano je do niwelacji nierówności w parku i otuliny oraz dróg dojazdowych. Materiał ten posłużył jednocześnie od użyźnienia gleb, nie zmieniając negatywnie warunków wzrostu drzew i krzewów.

\subsection{Zagospodarowanie $w$ budownictwie}

Urobek pozyskany w wyniku bagrowania można zastosować jako materiał budowlany. Wydobyte osady denne ze zbiorników wodnych mogą zastąpić naturalne grunty mineralne stosowane w budownictwie m.in.: do budowy nasypów hydrotechnicznych (w tym wałów przeciwpowodziowych), nasypów drogowych, do wykonywania przesłon mineralnych na składowiskach odpadów oraz budowy plaż i nabrzeży $[17,18,24,40]$.

Rozpoznanie udziału poszczególnych frakcji granulometrycznych oraz właściwości geotechnicznych osadów dennych jest ważne przy wyborze roli jaką mają pełnić w budownictwie. Wymogi odnośnie kryteriów, które powinny spełniać grunty do wykorzystania $\mathrm{w}$ budownictwie określają odpowiednie normy budowlane. Osad denny wykorzystywany w budownictwie musi spełniać kryteria geotechniczne dotyczące m.in.: wilgotności naturalnej, składu uziarnienia, granic konsystencji, gęstości właściwej, parametrów zagęszczenia (maksymalnej gęstości objętościowej szkieletu gruntowego i wilgotności optymalnej) współczynnika filtracji oraz parametrów wytrzymałości na ścinanie (kąta tarcia wewnętrznego i kohezji) [18, 24].

Bardzo ważnym kryterium ekonomicznym, które jest brane pod uwagę przy stosowaniu osadów dennych w budownictwie jest mała odległość ich położenia od miejsca budowy. Przykład takiego postępowania bardzo często jest spotykany przy budowie zapór ziemnych, gdzie technologie wznoszenia budowli dobiera się pod parametry materiałów miejscowych. Przy budowie zapór ziemnych kładzie się nacisk na jak największe wykorzystanie materiałów lokalnych, co znacznie obniża koszty inwestycyjne [19]. Przy budowie wałów przeciwpowodziowych kryteria wyboru skupiają się na dostępności materiału w przypadku konieczności napraw oraz utrzymania technicznego, dlatego często wykorzystuje się materiały miejscowe [37].

Budowa wałów przeciwpowodziowych z wykorzystaniem materiałów uznanych za odpady: osadów dennych, geosyntetyków oraz produktów spalania węgla była przedmiotem projektu Dredgdikes [46]. Projekt ten był realizowany w latach 2010-2014 przez zespół badawczy z Polski, Danii i Niemiec. Do celów doświadczalnych zbudowano wały badawcze w Niemczech w Maklemburgii-Pomorzu wykonane z mieszaniny urobku czerpalnego i geosyntetyków, zaś w Polsce z połączenia urobku czerpalnego i popiołożużli pochodzących ze spalania węgla [38]. Wykonawcy projektu pozytywnie ocenili wykorzystane materiały.

Zadaniem przesłon mineralnych jest zatrzymanie zanieczyszczeń w obrębie składowiska odpadów, przy jednoczesnym zapobieganiu przedostania się wód 
infiltracyjnych z opadów. Przykładowe badania nad oceną przydatności osadów dennych do formowania przesłon mineralnych na składowiskach odpadów prowadziła Koś i Zawisza [22]. Osady pochodziły ze Zbiornika Rzeszowskiego, wykonano badania parametrów fizykochemicznych oraz geotechnicznych. Stwierdzono przydatność badanych osadów dennych do budowy przesłon mineralnych na składowiskach odpadów z pewnymi zastrzeżeniami. Zaproponowano polepszenie właściwości geotechnicznych badanych osadów dennych poprzez dodatek substancji stabilizujących. Podobne badania zostały wykonane na osadach dennych Jeziora Rożnowskiego przez Gwoździa [17,18]. Właściwości tych osadów spełniły odpowiednie kryteria i zostały ocenione jako materiał nadający się do wykorzystania przy budowie przesłon mineralnych na składowiskach odpadów.

Koś i Zawisza [23] badali przydatność osadów dennych ze Zbiornika Rzeszowskiego również pod kątem zastosowania w budownictwie drogowym. Osady denne stabilizowano cementem i wapnem w celu poprawy wytrzymałości na ściskanie. $\mathrm{W}$ przypadku stabilizacji cementem uzyskano wartości nie spełniające wymagań stawianych materiałom wykorzystywanym w budownictwie drogowym, zaś osady stabilizowane wapnem mogą być stosowane do dolnych warstw ulepszonego podłoża drogi. Natomiast Kozielska-Soroka i Chęć [24] przeanalizowały właściwości osadów dennych pochodzących z Jeziora Czorsztyńskiego w aspekcie ich wykorzystania w budownictwie. Stwierdzono, że wysoki współczynnik filtracji pozwala na wykorzystanie osadów dennych do uszczelniania ziemnych budowli hydrotechnicznych, ale nie spełniają one kryteriów dopuszczalnych do użycia przy budowie nasypów drogowych i kolejowych ze względu na wysoki parametr granicy płynności.

\subsection{Zagospodarowanie w celu produkcji energii cieplnej}

Innym kierunkiem zagospodarowania osadów dennych jest energetyka. Możliwe jest pozyskania energii z osadów dennych w procesie spalania lub przy produkcji biogazu. Warunkiem stosowania osadów jako paliwo jest minimalna wartość opałowa wynosząca $10 \mathrm{MJ} / \mathrm{kg}$ [10], która zapewnia opłacalność ekonomiczną. Korzystne jest użycie osadów dennych w procesie współspalania $\mathrm{z}$ innymi paliwami alternatywnymi lub osadami ściekowymi w celu podwyższenie kaloryczności. Osad denny może być wykorzystany do celów opałowych po wstępnej obróbce, która polega na odsączeniu wody, dodaniu biokomponentu (do 30\% ilości wagowych) oraz materiału wiążącego jakim jest wapno (do $1 \div 4 \%$ ilości wagowych). Następnie całość jest wymieszana, przetworzona do formy granulatu, który po wysuszeniu nadaje się do wykorzystania [7].

Przeprowadzone przez Borsuka i in. [7] badania osadów dennych zbiornika Żur wykazały ich dużą wartość energetyczną. Oszacowano $80 \%$ zawartości materii organicznej w osadach, co przekłada się na wysoką wartość energetyczną ok. $14,5 \mathrm{MJ} \cdot \mathrm{kg}^{-1}$. Osady denne rozpatrywano w trzech warstwach w przekroju, przy czym stwierdzono, że najbardziej przydatne pod względem energetycznym 
zalegają w środkowej części. Sprawdzano również zastosowanie osadów jako materiału wiążącego po dodaniu do biokomponentów (m.in.: ścier drzewny, trociny, wytłoki), co pozwoliło na uzyskanie materiału opałowego o wysokich parametrach energetycznych ok. $18 \mathrm{MJ} \cdot \mathrm{kg}^{-1}$. Oceniono korzystnie wykorzystanie osadów dennych jako materiału opałowego. Natomiast DziałoszyńskaWawrzkiewicz $[10,11]$ prowadziła badania nad możliwością wykorzystania osadów dennych zanieczyszczonych mułem węglowym przez współspalanie w przemyśle cementowym i energetyce. Osady pochodziły ze zlewni rzeki Kłodnica zlokalizowanej w obszarze Górnośląskiego Obszaru Przemysłowego. Badania wykazały wysoką zawartość węgla w osadzie oraz brak zależności pomiędzy zawartością węgla a granulacją osadu. Wartości opałowa przy wilgotności średniej $30 \%$ wyniosła ponad $13 \mathrm{MJ} \cdot \mathrm{kg}^{-1}$. Badania wykonane pod kątem zawartości metali ciężkich w odniesieniu do RMŚ w sprawie rodzajów oraz stężeń substancji, które powodują, że urobek jest zanieczyszczony [34] kwalifikują osad jako zanieczyszczony. Osady oceniono jako spełniające normy do współspalania w przemyśle cementowym i energetyce.

Produkcja biogazu z osadów dennych jest możliwa z uwagi na posiadana przez nie dużą wartość opałową. Osady denne mogą być samoistnym źródłem gazów czego dowodzą m.in. Gruca-Rokosz [16] czy Kostecki i in. [21]. Kużdżał i Cichy [26] badali gaz wydobywający się z osadów dennych silnie zanieczyszczonego zbiornika zaporowego Dzierzno Duże. Analiza ilościowa i jakościowa składu gazu wykazała udział metanu w przedziale $73 \div 83 \%$, dwutlenku węgla $4,5 \div 22 \%$, azotu $3,9 \div 22,47 \%$. Skład gazu był zależny od temperatury, proporcjonalnie do wzrostu temperatury wody od $7^{\circ} \mathrm{C}$ do $24^{\circ} \mathrm{C}$ wzrastała ilość metanu i azotu, natomiast udział dwutlenku węgla malał. Ogólna ilość wydzielonego gazu, z uwzględnieniem wahań temperatury wody, była w zakresie $2 \div 12 \mathrm{dm}^{3} \cdot \mathrm{m}^{-2} \mathrm{~d}^{-1}$. Stwierdzono, że rozpuszczony w wodzie biogaz przyczynił się do znacznego pogorszenia warunków środowiskowych zbiornika.

\section{Podsumowanie}

Osady denne traktowane jako odpady muszą być odpowiednio zagospodarowane lub unieszkodliwiane. Przed wyborem sposobu ich wykorzystania potrzebna jest wiedza na temat ich składu fizyko-chemicznego, ewentualnego stopnia ich zanieczyszczenia substancjami antropogenicznymi. Należy rozpoznać także charakterystykę terenów na jakich mogą być składowane. Wykorzystanie osadów dennych do pozyskania energii wiąże się z możliwością uzyskania materiału opałowego, który będzie tanim naturalnym paliwem. Przed wykorzystaniem ich jako materiał $\mathrm{w}$ budownictwie niezbędne są dodatkowe badania geotechniczne. Zastosowanie osadów w budownictwie i rolnictwie jest rozwiązaniem, które może być odpowiedzią na niedobór materiału czy gleb w niektórych rejonach. Istotny jest w tym przypadku aspekt ekonomiczny. Ogólnie pozy- 
tywny przejaw wykorzystania osadów upatruje się w zmniejszeniu ryzyka skażenia gleby wynikające z ich niewłaściwego składowania.

Problem oceny osadów dennych do potencjalnych możliwości ich wykorzystania polega na braku jednoznacznych norm prawnych określających sposób postępowania $\mathrm{z}$ nimi. Wynika to $\mathrm{z}$ trudności oszacowania zagrożenia, jakie niosą ze sobą metale ciężkie zanieczyszczające osady, a dokładniej z ich mobilnością i biodostępnością w zróżnicowanych warunkach środowiska. Po wejściu w życie aktualnej Ustawy o odpadach nie istnieje podstawa prawna, która określała by dopuszczalny poziom zanieczyszczeń w pozyskanych osadach dennych, dlatego nadal stosuje sie uchylone RMŚ w sprawie rodzajów oraz stężeń substancji, które powodują, że urobek jest zanieczyszczony. $\mathrm{Z}$ uwagi na to, zaproponowany $\mathrm{w}$ pracy schemat postępowania $\mathrm{z}$ osadami dennymi uwzględnia zarówno Ustawę o odpadach, jak i wspomniane Rozporządzenie.

\section{Literatura}

[1] Abrasimowicz M., Niemiec M., Wiśniowska-Kielan B.: Zmiany odczyn gleby oraz fitoprzyswajalności niklu pod wpływem dodatku osadu dennego do podłoża, Proceedings of ECOpole, 2011, vol.5, no.2, 475-478.

[2] Abrasimowicz M., Wiśniowska-Kielan B., Niemiec M.: Post-Effect of Bottom Sediment Addition to the Substratum on Chemical Composition of White Mustard (Sinapis alba L.) Biomass. Part 1. Macroelements Content, Ecological Chemistry And Engineering. A, 2011, vol. 18, nr 9-10, 1175-1184.

[3] Baran A., Jasiewicz C., Tarnawski M.: Wpływ zbiornikowego osadu dennego na zmiany właściwości fizykochemicznych gleby lekkiej, Proceedings of ECOpole, 2009, vol.3, no.2, 403-408.

[4] Bartoszek L., Koszelnik P., Gruca-Rokosz R., Kida M.: Assessment of agricultural use of the bottom sediments from eutrophic Rzeszów reservoir, Rocznik Ochrony Środowiska, 2015, v. 17, 396-409.

[5] Bąk Ł., Górski J., Rabajczyk A.: Content of heavy metal compounds in bottom sediments of the Suchedniow water reservoir, Ecological Chemistry And Engineering. A, 2013, vol. 20, nr 7-8, 757-769.

[6] Bąk Ł., Górski J., Szeląg B.: Koncentracja metali ciężkich w wodzie i osadach dennych małego zbiornika wodnego w Kaniowie, Proceedings of ECOpole, 2014, vol.8, no.1, 119-125.

[7] Borsuk S., Kujawski E., Borsuk M.: Naturalny osad denny (NOD) jako potencjalne źródło ekologicznej energii odnawialnej. Inżynieria i Ochrona Środowiska, Wydawnictwo Uczelniane UTP, Bydgoszcz, 2012, 43-52.

[8] Canet R., Chaves C., Pomares F., Albiach R.: Agricultural use of sediments from the Albufera Lake (eastern Spain), Agriculture, Ecosystems \& Envronment, vol. 95, issue 1, April 2003, 29-36.

[9] Ciesielczuk T., Kusza G., Karwaczyńska U.: Przyrodnicze wykorzystanie osadów dennych w świetle obowiązujących przepisów, Rocznik Ochrony Środowiska, 2011, tom 13, 1327-1338. 
[10] Działoszyńska-Wawrzkiewicz M.: Analiza możliwości unieszkodliwiania osadów dennych zanieczyszczonych mułem węglowym na przykładzie wybranego odcinka rzeki antropogenicznie zmienionej, 2014 http://www.ietu.katowice.pl/aktual/ /Seminaria_IETU/20_02_2014/prezentacja_MDW.pdf [dostęp 20.08.2015].

[11] Działoszyńska-Wawrzkiewicz M.: Frakcjonowanie osadów dennych z wybranego odcinka rzeki zlewni Kłodnicy celem uzasadnionego technicznie sposobu wykorzy-

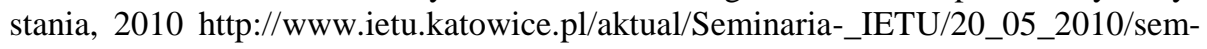
_maj_2010_MDW_www.pdf [dostęp 20.08.2015].

[12] Fonseca R., Barriga F.J.A.S., Fyfe W.S.: Reversing desertification by using dam reservoir sediments as agriculture soils, Episodes, 1998, vol. 21, no 4, 218-224 http://home.dgeo.uevora.pt/ rfonseca/fct_2009/Fonseca\%20et\%20-al\%20198.pdf [dostęp 20.08.2015 r.].

[13] Fonseca R., Barriga F.J.A.S., Fyfe W.S.: Suitability for agricultural use ofsediments from the Maranhão reservoir, Optimazation of Plant Nutrion, 1993, 665-671 http://link.springer.com/chapter/10.1007/978-94-017-2496-8_103 [dostęp 20.08.2015].

[14] Gałka B.: Ocena stopnia zanieczyszczenia i możliwości zagospodarowania osadów dennych z małych obiektów wodnych w parku we Wrocławiu-Pawłowicach. Ochrona Środowiska i Zasobów Naturalnych, 2010, 42, 233-239.

[15] Gałka B., Wiatkowski M.: Charakterystyka osadów dennych zbiornika zaporowego Młyny oraz możliwość rolniczego ich wykorzystania. Woda-Środowisko-Obszary Wiejskie, 2010, tom 10, z.4, 53-63.

[16] Gruca-Rokosz R.: Zbiorniki zaporowe jako źródło emisji gazów cieplarnianych, Inżynieria i Ochrona Środowiska, 2012, t.15, nr 1, 51-65.

[17] Gwóźdź R.: Właściwości geotechniczne osadów zdeponowanych w jeziorze rożnowskim oraz możliwości ich wykorzystania do budowy przesłon mineralnych w składowiskach odpadów komunalnych, Czasopismo Techniczne - Środowisko, Wydawnictwo Politechniki Śląskiej, z. 1-Ś/2008, 13-23.

[18] Gwóźdź R.: Właściwości osadów spoistych Jeziora Rożnowskiego w aspekcie ich geotechnicznego wykorzystania, Praca doktorska, Politechnika Krakowska, 2007.

[19] Jasiewicz Cz., Madeyski M., Tarnawski M., Baran A.: Zawartość metali ciężkich w biomasie kukurydzy pod wpływem dodatku osadu dennego do gleby, http://www.pzits.not.pl/docs/ksiazki/Ekotoks_2008/Jasiewicz\%20147-152.pdf [dostęp: 20.08.2015].

[20] Jancewicz A., Dmitruk U., Tomczuk U.: Potencjalne możliwości zagospodarowania osadów dennych na podstawie polskich przepisów prawnych, Gospodarka wodna, 2014, nr 3, 111-113.

[21] Kostecki M., Mazierski J., Kowalski E.: Emisja biogazu z osadów dennych zbiornika wodnego w warunkach silnej antropopresji, Archiwum Ochrony Środowiska, 2004, vol. 30, no. 1, 79-90.

[22] Koś K., Zawisza E.: Ocena przydatności osadów dennych Zbiornika Rzeszowskiego do budowy uszczelnień w składowiskach odpadów komunalnych, Acta Scientiarum Polonorum. Formatio Circumiectus, 2012, tom 11, nr 4, 49-60.

[23] Koś K., Zawisza E.: Stabilization of bottom sediments from Rzeszowski Reservoir, Annals of Warsaw University of Life Sciences - SGGW Land Reclamation, 2015, no 47, 2, 127-137. 
[24] Kozielska-Sroka E., Chęć M.: Właściwości osadów dennych Jeziora Czorsztyńskiego w aspekcie ich wykorzystania w budownictwie ziemnym. Górnictwo i Geoinżynieria, 2009, R. 33, z.1, 369-376.

[25] Kozlovska J., Petraitis E., Šerevičienè V.:Rresearch of heavy metals distribution in bottom sediment of Lake Talkša (Lithuania), Proceedings of ECOpole, 2012, vol.6, no.1, 99-103.

[26] Kużdżał E., Cichy B.: Ocena możliwości zagospodarowania osadów dennych rzek terenów uprzemysłowionych na przykładzie rzeki Kłodnicy, Ochrona Powietrza i Problemy Odpadów, 2008, vol. 42, nr 6, 167-174.

[27] Madeyski M., Tarnawski M.: Ocena stanu ekologicznego osadów dennych wybranych małych zbiorników wodnych, Infrastruktura i Ekologia Terenów Wiejskich, PAN Kraków, 2006, nr 4/3, 107-116.

[28] Madeyski M., Tarnawski M.: Wstępna ocena ilości osadów dennych wydzielonej części zbiornika wodnego "Besko" na rzece Wisłok, Infrastruktura i Ekologia Terenów Wiejskich, PAN Kraków, 2007, nr 4/1, 101-110.

[29] Michalec B.: Qualitative and quantitative assessment of sediments pollution with heavy metals of small water reservoirs. In: Soil health and land use management. Ed. M.C. Hernandez-Soriano. 2012, Croatia: InTech, 255-278.

[30] Niemiec M.: The influence of bottom sediments added to grounds on the quantity biomass of plants, https://mnet.mendelu.cz/mendelnet2006/arti-cles/enviro/niemiec.pdf [dostęp: 20.08.2015].

[31] Olsson S., Regnell J., Persson A., Sandgren P.: Sediment-chemistry re-sponse to land-use change and pollutant loading in a hypertrophic lake, southern Sweden. Journal of Paleolimnology, 1997, nr 17, 275-294.

[32] Popenda A., Malina G., Siedlecka E.: Składowanie jako metoda unieszkodliwiania osadów dennych zanieczyszczonych metalami ciężkimi, Ochrona Środowiska i Zasobów Wodnych, 2007, nr 32, 246-252.

[33] Rozporządzeniem Ministra Gospodarki z dnia 8 stycznia 2013 r. w sprawie kryteriów oraz procedur dopuszczania odpadów do składowania na składowisku odpadów danego typu (Dz. U. 2013, poz. 38).

[34] Rozporządzenie Ministra Środowiska z dnia 16 kwietnia 2002 r. w sprawie rodzajów oraz stężeń substancji, które powodują, że urobek jest zanieczyszczony (Dz. U. 2002 nr 55 poz. 498) (uchylone z dniem 1 stycznia 2014 r.).

[35] Rozporządzenie Ministra Środowiska z dnia 9 września 2002 r. w sprawie standardów jakości gleby oraz standardów jakości ziemi (Dz.U. $2002 \mathrm{Nr} 165$ poz. 1359).

[36] Rozporządzenie Ministra Środowiska z dnia 9 grudnia 2014 r. w sprawie katalogu odpadów (Dz. U. 2014 poz. 1923).

[37] Saathoff, F., Sikora Z., Cantré S.: Wytyczne programu Południowego Bałtyku: Zastosowanie Urobku Czerpalnego, Produktów Spalania Węgla oraz Geosyntetyków do Budowy Wałów Przeciwpowodziowych : Polish version. : Eigenverlag, 2015. http://www.dredgdikes.eu/wpcontent/uploads/DredgDi- kes_Guideline_PL_online.pdf [dostęp 20.08.2015].

[38] Sikora Z., Duszyński R., Cantré S.: Projekt DredgDikes - wykorzystanie urobku z robót czerpalnych do budowy wałów przeciwpowodziowych, Inżynieri Morska i Geotechnika, 2013, nr 1, 64-69. 
[39] Stanińska J., Szczepaniak Z., Picz K., Piotrowska-Cyplik A.: Assessment of the potential of Malta lake sediments in Poznan towards their use for agricultural purposes, Journal of Research and Applications in Agricultural Engineering, 2014, vol. 59, no 1, 116-120.

[40] Staniszewska M., Boniecka H., Gajda A.: Prace pogłębiarskie w polskiej strefie przybrzeżnej - aktualne problemy, Inżynieria Ekologiczna, 2014, vol. 40, 157-172.

[41] Tomczuk U., Dmitruk U., Jacewicz A.: Metodyka badań i oceny jakości osadów dennych zbiorników wodnych. Gaz, Woda i Technika Sanitarna, nr 9, 2014, 350-355.

[42] Tomczuk U., Dmitruk U., Jacewicz A.: Wdrożenie metodyki badania i oceny jakości osadów dennych zbiorników wodnych, Gaz, Woda i Technika Sanitarna, nr 11, 2014, 441-444.

[43] Ustawa z dnia 10 lipca 2007 r. o nawozach i nawożeniu (Dz. U. 2007 nr 147 poz. 1033 z późn. zm.).

[44] Ustawa z dnia 14 grudnia 2012 r. o odpadach (Dz. U. 2013 nr 0 poz. 21).

[45] Wiśniowska-Kielan B., Abrasimowicz M., Niemiec M.: Post-Effect of Bottom Sediment Addition to the Substratum on Chemical Composition of White Mustard (Sinapis alba L.) Biomass. Part 2. Quantitative Ratios between Macroelements, Ecological Chemistry And Engineering. A, 2012, vol. 19, nr 4-5, 387-393.

[46] http://www.dredgdikes.eu/pl/ [dostęp 20.08.2015].

\section{METHODS OF THE MANAGEMENT OF BOTTOM SEDIMENT}

\section{S u m m a r y}

Bottom sediments are accumulated sedimentary material which is extracted from the bottom of water bodies in order to enhance their capacity and to improve the retention values. Extracted bottom sediments that do not contain harmful substances may be used or stored. The composition of the bottom sediments is addicted to natural and anthropogenic factors. The results of part of the self-cleaning processes of pollutants from water reservoirs into the bottom sediment where they are retained. For this reason, the composition of the bottom sediments and surface waters are dependent. This relationship is particularly noticeable in the case of pollution, which are characterized by a low solubility and hardly biodegradable, such as salts of heavy metals and persistent organic compounds. The choice of how the management of bottom sediments depends on their chemical and physical properties. It is possible to use bottom sludge for agriculture, construction or for the production of thermal energy. In the article discusses the possible use of bottom sediments and the criteria for its management. On the basis of the criteria discussed proposed schema dealing with sediment on bottom trawls.

Keywords: bottom sediments, reservoir, quality of bottom sedimenta, contaminated sediments bottom

Przestano do redakcji: $10.02 .2016 r$.

Przyjęto do druku: $1.03 .2016 r$.

DOI: $10.7862 /$ rb.2016.118 
